Катинка Беретка (Beretka Katinka) ${ }^{1}$ Факултет за правне и пословне студије „Др Лазар Вркатић” Нови Сад
Оригинални научни рад

UDK $342.724 / .725(=163.41)(497.5)$

Примљено: 07.12.2020.

Ревидирана верзија: 03.3.2021.

Одобрено за штампу: 04.3.2021.

DOI: https://doi.org/10.46630/gsoc.26.2021.05

\title{
ПРАКСА УСТАВНОГ СУДА РЕПУБЛИКЕ ХРВАТСКЕ У ОБЛАСТИ ПРАВА НАЦИОНАЛНИХ МАНИНА, СА ПОСЕБНИМ ОСВРТОМ НА ЈЕЗИЧКА ПРАВА СРПСКЕ ЗАЈЕДНИЦЕ У ХРВАТСКОЈ²
}

\begin{abstract}
Ancтракт: У периоду од 2000. године до данашњег дана Уставни суд Републике Хрватске се често суочавао са изазовом одлучивања о политички осетљивим темама, нарочито када се радило о потреби за заштитом права, како традиционалних, тако и права такозваних „нових” мањинских заједница - које су формирањем нових самосталних националних држава

настале од некадашњих конститутивних народа бивше Југославије. Случајеви који се јављају у пракси суда, разноврсни су, али се по предмету претежно односе на културну аутономију, представљање припадника националних мањина у локалним, односно регионалним представничким телима и равноправну заступљеност у јавном сектору, као и на (службену) употребу језика и писма. Подносиоци уставних тужби, односно иницијатори поступака оцене уставности и законитости општих правних аката вођени су разним мотивима; а питање је да ли су ови мотиви били од утицаја на рад уставног суда, то јест да ли је суд приликом одлучивања остао веран својој првобитној улози да штити основне, безвременске вредности уставног поретка Хрватске или се руководио програмима актуелне партијске политике.

Поред генералног представљања правне регулативе мањинских права, односно надлежности уставног суда у Хрватској уз помоћ правно научних метода, у раду се посебно анализирају случајеви у вези са језичким правима „нових” мањинских заједница, фокусирајући се на аргументацију „обе стране” односно уставног суда у току поступка. Циљ рада је да се преко конкретних уставносудских предмета представи пракса Уставног суда Хрватске у области језичких права националних мањина, са посебним освртом на доследност аргументације суда.
\end{abstract}

Кључне речи: Хрватска, уставни суд, националне мањине, нове мањине, језичка права, службена употреба језика

\footnotetext{
1 beretka.katinka@gmail.com

${ }^{2}$ Истраживање је спроведено у оквиру програма Министарства правде Мађарске за развијање образовања правника.
} 


\section{Представљање проблема}

У складу са владајућим схватањем из међународне литературе такозване старе мањине (другим речима историјске, традиционалне, аутохтоне) чији се језик, култура, религија значајно разликују у односу на већину становништва, настале су изменом државних граница, односно променом суверена над њиховом територијом, док се нове мањине дефинишу као групе појединаца и породица са миграцијском позадином које су напустиле своје матичне државе због економских или политичких разлога (избеглице, мигранти) (Medda-Windischer 2017: 26-27). С друге стране, постоји озбиљна разлика између разних категорија нових мањина, нарочито када се овај појам истражује у другачијем контексту, у светлу дешавања на Западном Балкану од почетка деведесетих.

У последње три деценије земље у региону су се без изузетка суочиле са бројним изазовима који су били резултат политичке, економске и друштвене трансформације након распада социјалистичке Југославије. Поред изградње пријатељских билатералних односа између нових самосталних националних држава на Балкану, државе су морале да уложе озбиљне напоре и у ублажавање сукоба унутар граница који су се неретко јавили као нужан резултат промена у етничкој, језичкој и религијској структури становништва. Некадашњи конститутивни народи држава чланица Социјалистичке Федеративне Републике Југославије (Србије, Хрватске, Словеније, Црне Горе, Северне Македоније и Босне и Херцеговине) одједном су се нашли у мањинској позицији са сличним или истим статусом, правима и обавезама као традиционалне мањинске заједнице (тј. народности СФРЈ). Грађани који не припадају већинском народу дате државе Западног Балкана, али до престанка федералног уређења нису имали ни положај националне мањине, такође се називају новим мањинама (Kuntić 2003: 35) које су почеле да изграђују своје институције само у скорије време, односно још су у фази организовања (Tatalović 2006: 172), за разлику од традиционалних/старих мањина које ефикасније и боље остварују своја права због вишедеценијске борбе за иста. Иако постоји мишљење да разликовање ових мањина има смисла само када се говори о политичком односу према њима, и у стварности обе врсте се третирају на једнак начин (Радушки 2012: 445), свака држава има суверено право да категоризује или не категоризује своје етничке групе, и тако да прави или не прави разлику у погледу правног положаја старих и нових мањина. На пример у Словенији мађарска и италијанска национална заједница по самом Уставу имају статус „аутохтоних заједница“ чија се права регулишу посебним законом ${ }^{3}$ (Устав Републике Словеније, члан 5 и 64), ${ }^{4}$ док ромска заједница такође ужива шири спектар права по посебном закону, али

3 Статус и посебна права италијанске и мађарске националне заједнице детаљније регулише Закон о самоуправним националним заједницама. Zakon o samoupravnih narodnih skupnostih, Uradni list $R S$, št. 65/94 in 71/17.

${ }^{4}$ Ustav Republike Slovenije, Uradni list Republike Slovenije, št. 33/91-I, 42/97 - UZS68, 66/00 UZ80, 24/03 - UZ3a, 47, 68, 69/04 - UZ14, 69/04 - UZ43, 69/04 - UZ50, 68/06 - UZ121,140,143, 47/13 - UZ148, 47/13 - UZ90,97,99 in 75/16 - UZ70a. 
без признатог аутохтоног статуса (Устав Републике Словеније, члан 65). ${ }^{5}$ Остале мањинске групе, тако и нове мањине, имају ограничен круг права: могу да користе свој матерњи језик у службеној комуникацији само преко тумача. Уставна категоризација мањина у овом примеру није резултат величине дате мањинске популације у Словенији, него „дужина њиховог континуираног суживота са већинским словеначким народом на појединим деловима територије данашње Словеније кроз историју, а вероватно и њихова културна и верска блискост са већинским народом” (Теофиловић 2020: 219).

У Републици Хрватској не постоји правно диференцирање између националних мањина слично словеначком моделу. У темељним принципима (изворишним основама) Устава Републике Хрватске Хрватска се дефинише као „национална држава хрватског народа и држава припадника националних мањина: Срба, Чеха, Словака, Талијана, Мађара, Жидова, Нијемаца, Аустријанаца, Украјинаца, Русина, Бошњака, Словенаца, Црногораца, Македонаца, Руса, Бугара, Пољака, Рома, Румуна, Турака, Влаха, Албанаца и других“ (Устав Републике Хрватске, Изворишне основе, став 2), ${ }^{6}$ којима се гарантује равноправност не само међусобно, него и са већинским народом. Законска дефиниција националне мањине такође не раздваја мањине у посебне групе: национална мањина представља скуп хрватских држављана чији су припадници традиционално настањени на територији Републике Хрватске, а њени чланови имају етничка, језична, културна и/или верска обележја различита од других грађана (Уставни закон о правима националних мањина, члан 5). ${ }^{7}$

Према попису становништва из 2011. године, од пописаног 4.284.889 становника 7,67\% је (био) припадник националних мањина, али ниједна мањинска група није прешла праг од 1\%, осим српске националне заједнице која представља 4,36\% укупног становништва (Државни завод за статистику Републике Хрватске 2013: 11). Срби у хрватском друштву због своје специфичне политичкоисторијске позиције се и даље налазе негде између интеграције и асимилације, и према којима припадници хрватског народа имају највећу социјалну дистанцу (Радушки 2012: 451). Независно од формалне заштите мањинских права, укључујући и колективна, обезбеђена у разним правним прописима, Срби због своје територијалне дисперзије ретко могу да их остварују у потпуности (Радушки 2012: 452), нарочито када се ради о остваривању језичких права пред органима власти. У току петог мониторинг циклуса примене Европске повеље о регионалним или мањинским језицима у Хрватској ${ }^{8}$, Комитет експерата је истакао да тешкоћа у вези са употребом српског језика и ћириличког писма представља специфичан проблем у држави, а Срби често и одустају од упо-

\footnotetext{
${ }^{5}$ Статус и посебна права ромске заједнице уређује Закон о ромској заједници у Републици Словенији. Zakon o romski skupnosti v Republiki Sloveniji, Uradni list RS, št. 33/07.

${ }^{6}$ Ustav Republike Hrvatske, Narodne novine, br. 56/90, 135/97, 113/00, 28/01, 76/10, 5/14.

${ }^{7}$ Ustavni zakon o pravima nacionalnih manjina, Narodne novine, br. 155/02, 47/10, 80/10.

${ }^{8}$ Повеља је ступила на снагу у Хрватској 1. марта 1998. године. Тренутно је у току шести мониторинг циклус и чека се финална препорука Комитета министара.
} 
требе свог писма због страха од изазивања нетрпељивости других. Ова констатација Комитета је била потврђена и у шестом, текућем циклусу, с тим да су додали да се ситуација у неким областима чак и погоршала (Committee of Experts 2020: 16). Прва и посебно наглашена препорука Комитета је била да се равноправна службена употреба српског језика и припадајућег писма у локалним и регионалним органима власти прошири и на друге локалне самоуправе, али значај ове области наглашава и чињеница да су се од осталих шест препорука још четири односиле на службену употребу језика (а преостале две на јавно информисање и образовање). Препоручено је предузимање мера у циљу промовисања подношења поднесака, односно објављивања службених текстова и образаца на српском језику и ћириличком писму, шире употребе српског језика у току пружања јавних услуга, и коришћења топографских назива на српском језику (Committee of Experts 2020: 47-48).

1954. године у Новом Саду, водећи писци и лингвисти српско-хрватског језика, како се језик звао у Србији, односно, хрватско-српског језика, како се звао у Хрватској, сложили су се о унификацији терминологије српског и хрватског језика, и стварању заједничке ортографије (тзв. Новосадски договор) што је било више него пожељно за новоформирану заједницу пријатељских народа у атмосфери братства-јединства (Бугарски 2004: 28). Али заједнички језик престао је службено да постоји распадом Југославије: „Дете југословенске идеје поделило је њену судбину од самог почетка, и било је сахрањено у исти ковчег заједно са федерацијом чије несигурно јединство је симболизовало и делом подржавало" (Бугарски 2004: 30). Зато није ни чудно да је употреба ћириличког писма - које је иначе једино писмо које се спомиње по називу у самом Уставу Републике Србије, односно које је у службеној употреби на територији Србије без потребе за даљом законском разрадом (Устав Републике Србије, члан 10$)^{9}$ - постала политички симбол идентитетске политике српског народа како унутар границе Србије, тако у дијаспори. „Неки Срби и Црногорци ћирилицу поистовећују с етничком припадношћу, чак и с православљем, а латиницу с нечим што је туђе властитој култури, с нечим страним, с католицизмом" (Багдасаров 2018: 51). У Хрватској у службеној употреби су хрватски језик и латинично писмо, али поштујући законске услове и други језици заједно са припадајућим писмима могу да се уведу у службену употребу у појединим локалним заједницама (Устав Републике Хрватске, члан 12). Чињеница да је ћириличко писмо посебно наведено у датој уставној одредби -,у службену употребу се може увести и други језик, те ћириличко или које друго писмо" (Устав Републике Хрватске, члан 12 став 2) - указује на релевантност ове друштвено-политичке теме не само у хрватском друштву као таквом, него и на нивоу највишег правног акта, устава.

У последње време регулисање статуса разних језика у службеној употреби задобило је већу пажњу, иза чега стоје два процеса: 1) изградња нових националних држава у којима власт покушава да хомогенизује иначе хетерогену

\footnotetext{
${ }_{9}^{9}$ Устав Републике Србије, Службени гласник Републике Србије, бр. 98/2006.
} 
популацију уз помоћ једног заједничког језика (језика државе или службеног језика), и 2) промењена улога и проширене функције државе у скоро свим областима друштвеног живота због чега се значајно повећао број свакодневних интеракција између грађана и органа власти, што је ефикасније, економичније ако се одвија само на једном језику (Korhecz 2013: 95-96). Имајући у виду да су националне државе неретко настале на мултијезичним, мултикултуралним територијима где се људи служе различитим језицима, разумљиво је да наметање једног језика - најчешће језика националне већине - на којем се може комуницирати са државом изазива противљење од стране других националности, то јест националних мањина, било традиционалних, било нових. С друге стране, ради се о области језичких права која има највише (директне) везе са политиком, и на овај начин најлакше рефлектује актуелне политичке, а и друштвене односе у држави.

У овом раду поред оквирног представљања правне регулативе језичких права националних мањина у Хрватској, односно основних надлежности и праксе Уставног суда Хрватске у области заштите тих права тражи се одговор на питање да ли је Уставни суд Хрватске успео да остане политички неутралан приликом одлучивања о правима мањина на службену употребу свог језика и писма у неретко политички мотивисаним или надахнутим поступцима - нарочито када се радило о језичким правима српске заједнице у Хрватској или да ли је макар покушавао да буде заштитнички настројен према националним мањинама.

\section{Језичка права националних мањина у Хрватској}

Члан 15 Устава Републике Хрватске, иако врло оскудно регулише мањинска права, припадницима свих националних мањина гарантује равноправност, слободу изражавања националне припадности, слободу употребе матерњег језика и писма, културну аутономију и право избора својих представника у Хрватском сабору. Даља законска разрада је учињена у тзв. Уставном закону о правима националних мањина. Иако се зове Уставни закон, заправо представља обичан органски закон, како је дефинисан Уставом Републике Хрватске, који се усваја двотрећинском већином гласова свих посланика у Хрватском сабору (Устав Републике Хрватске, члан 83 став 1). Ова квалификована већина се тражи и за промену границе Хрватске (члан 8), за ограничење људских права за време ратног и ванредног стања (члан 17 став 1), за покретање поступка за утврђивање посебне одговорности председника републике у Сабору, односно за одлучивање о његовој/њеној одговорности од стране Уставног суда (члан 105 став 2-3), за ратификацију међународних уговора (члан 133 став 2), односно за удруживање Хрватске у савезе са другим државама (члан 135 став 3). Према Уставу, двотрећинска већина се тражи једино за промену самог Устава (Устав Републике Хрватске, члан 138), а није предуслов за доношење ниједног 
другог „обичног” секторског закона, осим Уставног закона о правима мањина. ${ }^{10}$ Остали органски закони којима се разрађују Уставом утврђена људска права и слободе, избор, уређење и надлежности државних органа, односно уређење и делокруг локалне и подручне (регионалне) самоуправе доносе се већином гласова свих посланика у Хрватском сабору (Устав Републике Хрватске, члан 83 став 2). Чињеница да је иста већина прописана за доношење закона којима се регулишу права националних мањина и за промену Устава указује на изузетан значај ове материје у држави, у којој је потреба за политичким компромисом израженија него у свим осталим питањима - макар према уставотворцу. С друге стране, у хијерархији правних аката у Хрватској, Уставни закон о правима мањина нема већу правну снагу од осталих закона, нити се налази на истом степену хијерархијске лествице са другим „правим” уставним законима, какав је на пример Уставни закон о Уставном суду Републике Хрватске, који има карактер уставног закона не само по називу, него и по посебном поступку усвајања - доноси се по процедури предвиђеној за промену устава (Устав Републике Хрватске, члан 127). Према Уставном суду falsa nominatio не мења правну природу закона на основу чега га суд оцењује (тачка 5 одлуке Уставног суда Републике Хрватске под бр. U-I-774/2000 од 20. 12. 2000), зато је и у сукобу ова два уставна закона дао предност Уставном закону о Уставном суду над Уставним законом о правима мањина (тачка 5-8. одлуке Уставног суда Републике Хрватске под бр. U-I-1029/2007 од 07. 04. 2010). Ово питање можда изгледа теоријско, али у пракси Уставног суда Хрватске добило је и своју практичну димензију у случају колизије Уставног закона о правима мањина и других органских или „обичних” закона. Један од примера ће бити касније посебно анализиран због уске повезаности са предметом овог рада (одлука Уставног суда Републике Хрватске под бр. U-III-4856/2004 од 12. 03. 2007. године, случај двојезичне личне карте).

Уставни закон о правима националних мањина садржи класичан каталог индивидуалних и колективних мањинских права, као што су употреба личног имена, служење својим језиком и писмом, приватно и у јавној употреби, те у службеној употреби, право на образовање на матерњем језику, употреба симбола, одржавање, развој и исказивање властите културе попут културне аутономије, манифестација вере, приступ средствима јавног информисања и информисање на свом језику, самоорганизовање и удруживање ради остваривања заједничких интереса, сразмерна заступљеност у јавном сектору, управљање локалним пословима путем већа, односно представника (Уставни закон о правима националних мањина, члан 7). ${ }^{11}$ Наравно, мањинска права се регулишу и низом других специјалних закона на које се и сам Уставни закон на више места

\footnotetext{
10 Двотрећинска већина се тражи и за доношење Уставног закона о Уставном суду Републике Хрватске, али за разлику од Уставног закона о правима мањина, овај закон је „прави” уставни закон, који се доноси у процедури предвиђеној за промену Устава, док Уставни закон о правима мањина, према интерпретацији Уставног суда, је обичан секторски закон.

${ }^{11}$ Ustavni zakon o pravima nacionalnih manjina, Narodne novine, br. 155/02, 47/10, 80/10.
} 
директно или индиректно позива, међу којима је и Закон о употреби језика и писма националних мањина (Уставни закон о правима националних мањина, члан 12 став 2).

Говорећи о језичким правима националних мањина важно је напоменути да се, с једне стране, Уставним законом гарантују типична језичка права; то су пре свега она у вези са службеном употребом језика, а с друге стране и друга права код којих матерњи језик националне мањине није примарни предмет заштите, али остваривање ове групе права је незамисливо без слободне употребе матерњег језика, као на пример право на образовање или информисање (Beretka 2019: 43). Иначе већина људских права је уско повезана са проблематиком такозване језичке слободе што по правилу значи да беспрекорно остваривање скоро свих основних људских права није могуће ни за националну већину, нити за националне мањине без универзалног признавања њиховог права на употребу свог матерњег језика (или слободно изабраног језика). На пример, шта вреди слобода изражавања без слободне употребе језика, односно без слободе самог језика (Andrássy 2013: 12), или да ли право на образовање има смисла ако дете не разуме језик на којем се настава изводи. Поново наглашавамо да се у оквиру овог рада фокусира само на оне случајеве пред Уставним судом Хрватске који се директно тичу употребе мањинских језика у службеној комуникацији.

С обзиром на карактер оквирног закона, Уставни закон о правима мањина не регулише детаљно било коју групу права, него садржи смернице за њихово даље регулисање другим специјалним законима. У складу са тим прописује да припадници националне мањине могу да користе свој језик под равноправним условима са хрватским језиком пред органима власти у јединицама локалне самоуправе, уколико припадници конкретне националне мањине чине једну трећину локалног становништва (Уставни закон о правима националних мањина, члан 12 став 1); али равноправна службена употреба мањинског језика може да се остварује и када је то предвиђено ратификованим међународним уговором, и када је то прописано статутом јединице локалне, односно подручне самоуправе, у складу са одредбама Закона о употреби језика и писма националних мањина (Уставни закон о правима националних мањина, члан 12 став 2). Иначе овај закон уместо цензуса од једне трећине локалног становништва, како је предвиђено Уставним законом о правима мањина, предвиђа оштрији услов: за увођење једног мањинског језика у службену употребу припадници те националне мањине треба да чине већину у локалној популацији (Закон о употреби језика и писма националних мањина, члан 4 став 1). ${ }^{12}$ Ова колизија може да се објасни чињеницом да је Закон о употреби језика и писма донет пре усвајања Уставног закона о правима мањина, а све до данас није извршено усаглашавање текстова. На основу начела lex posterior derogat legi priori ${ }^{13}$

\footnotetext{
${ }^{12}$ Zakon o uporabi jezika i pisma nacionalnih manjina u Republici Hrvatskoj, Narodne Novine, br. 51/00, 56/00

${ }^{13}$ Касније донесени закон поништава пређашњи.
} 
примењује се касније донет закон, то јест у овом случају Уставни закон који прописује блажи услов (Petričušić 2013: 18).

У шестом извештају Хрватске у току мониторинга примене Европске повеље о регионалним или мањинским језицима наведено је да су на основу испуњења критеријума из законског цензуса чешки, мађарски, италијански и словачки језици уведени у службену употребу у једној локалној самоуправи, а српски у 23. Две локалне самоуправе су добровољно увеле још чешки језик, три локалне самоуправе мађарски, 19 локалних самоуправа италијански, а једна локална самоуправа русински и српски, иако мањинска популација није достигла једну трећину у локалном становништву ни у једном наведеном случају (Committee of Experts 2020: 8).

Као услов приступања Европској унији (Andeva \& Beretka 2018: 168), Xpватска је ратификовала два најзначајнија документа Европског савета у овој области: већ споменуту Европску повељу о регионалним или мањинским језицима и Оквирну конвенцију о заштити права националних мањина. ${ }^{14}$ У својим годишњим извештајима о напретку државе Европска комисија се посебно позивала на констатације до којих су експертски одбори дошли у току мониторинга примене наведених конвенција, и генерално сматрала да је пракса употребе мањинских језика коректна (Tatalović b. d. 8), али није ишла у детаље што се тиче положаја појединих мањина и њихових матерњих језика у стварности. Уз мултилатералне Хрватска је склопила и билатералне уговоре са појединим државама у области заштите права националних мањина: са Италијом, Мађарском, Северном Македонијом, Србијом, Црном Гором, Чешком и Аустријом (Radaković \& Mikić b. d. 14). Иако билатерални уговори такође могу да представљају извор језичких права мањина - по Уставном закону о правима мањина - уместо прописивања нових права или услова за остваривање истих, по правилу садрже soft law мере за државе потписнице без ефективног механизма за контролу извршења тих „меких“ обавеза.

Службена употреба мањинских језика, у смислу Уставног закона, подразумева употребу језика у раду представничких и извршних тела општине, града и жупаније, у управним поступцима пред локалним, односно регионалним органима на првом и другом степену, и органима државне управе на првом степену, у судским поступцима на првом степену, у поступцима пред јавним бележницима и државним јавним тужиоцем, односно свим другим организацијама са јавним овлашћењима (Уставни закон о правима националних мањина, члан 12 став 3), а Закон о употреби језика и писма националних мањина посебно и детаљно регулише околности равноправне службене употребе мањинских језика пред свим наведеним органима, односно организацијама. На пример, шта треба обезбедити и на мањинском језику када се рад представничког и других локалних, односно регионалних тела одвија двојезично или вишејезично: исписивање текста печата и жигова, натписних плоча и заглавља

\footnotetext{
${ }^{14}$ Хрватска је ратификовала Оквирну конвенцију 11. октобра 1997. године, а ступила је на снагу 1. фебруара 1998. године.
} 
аката истом величином слова, достављање материјала и позива за седницу, израда записника и објављивање закључака и других службених обавештења и на мањинском језику (Закон о употреби језика и писма националних мањина, члан 8). Надаље, грађани имају право да захтевају јавне исправе на мањинском језику, односно двојезично штампане службене обрасце (Закон о употреби језика и писма националних мањина, члан 9), да се њихове приватне исправе састављене на мањинском језику признају пуноправним (члан 5 став 2), али закон ћути о могућности усменог обраћања на мањинским језицима.

Што се тиче употребе језика националне мањине у поступцима, битно је напоменути да се равноправност хрватског и мањинских језика може остварити једино под условом да се све процесне радње предузимају (и) на мањинском језику; што практично значи да сви учесници, почев од странке, преко записничара све до судије/службеног лица које води поступак, говоре (или макар разуме) исти језик. Уколико странка може да користи свој матерњи језик само уз помоћ тумача у току поступка (које је право иначе гарантовано, на пример, осумњиченим, окривљеним и оптуженим лицима која не разумеју језик кривичног поступка, без обзира на њихову припадност некој националној мањини) (Устав Републике Хрватске, члан 29 став 2 тачка 7) не можемо говорити о остваривању права на вођење поступка паралелно и на мањинском језику. Закон о употреби језика прописује да странка има право да користи свој језик у поступку, и да се о жељеном језику изјасни на записник (члан 12 став 1), односно да се језик на којем је написан први поднесак странке сматра језиком којим жели да се служи у току даљег поступка (члан 13 став 2). Касније странка упућује своје поднеске на хрватском или на свом језику, по слободном избору (члан 16 став 2). Прво службено писмено се увек доставља на хрватском језику и на свим језицима који су уведени у службену употребу на територији општине, града, односно жупаније (члан 13 став 1), а поступајући орган је у обавези да обезбеди суделовање странке у поступку на изабраном језику, односно да му се достављају отправци свих донетих аката поред хрватског језика и на језику којим се служи (члан 14). Другостепени поступак се по правилу води на хрватском језику и латиничном писму (члан 19 став 1). На основу формулације наведених одредаба може се закључити да у Хрватској не постоји право на вођење стварно вишејезичних поступака, него само могућност употребе мањинског језика у току целог првостепеног поступка, највероватније преко тумача. За разлику од хрватског модела, у Србији Закон о службеној употреби језика и писама јасније регулише ово питање: „Првостепени управни, кривични, парнични или други поступак у коме се решава о правима и дужностима грађана води се на српском језику. / Поступак из става 1 овог члана може се водити и на језику националних мањина који је у службеној употреби у органу, односно у организацији која води поступак” (Закон о службеној употреби језика и писама, члан 12 став $1-2){ }^{15}$

15 Закон о службеној употреби језика и писама, Службени гласник Републике Србије, бр. 45/91, 53/93, 67/93, 48/94, 101/2005 - др. закон, 30/2010, 47/2018 и 48/2018 - испр. 
У области визуелне употребе језика саобраћајни знаци, називи улица, тргова и места исписују се двојезично, односно вишејезично, на целом подручју локалне самоуправе, или само на појединим деловима, у складу са статутом општине, односно града, а такође се статутом прописује да ли се и код којих места користе традиционални називи (Закон о употреби језика и писма националних мањина, члан 10). Уставни закон о правима мањина посебно предвиђа да статутима и/или Законом о употреби језика могу да се прописују мере ради очувања класичних назива и ознака на подручјима традиционално или у знатнијем броју насељеним припадницима националних мањина, односно да се насеља, улице и тргови називају по личностима и догађајима од значаја за историју и културу одређене националне мањине у Хрватској (Уставни закон о правима националних мањина, члан 13).

Службена употреба језика је предмет и других материјалних (закона о матичним књигама, личним картама, путним исправама, локалним самоуправама, итд.) и процесних закона (закона о грађанским, кривичним, управним поступцима, итд.), али имајући у виду да је Уставни суд Хрватске првенствено заснивао своје одлуке на горе наведена два закона, одустајемо од представљања других одредаба које иако могу да буду релевантне за регулисање језичких права уопште, нису релевантне у конкретном предмету овог рада.

\section{Кратак приказ уставносудских надлежности и праксе у Хрватској}

Република Хрватска је прихватила немачко-аустријски систем уставног судства, што се сматра и класичним европско-континенталним моделом. У погледу уставно правног статуса овог тела не постоји значајна разлика између Србије и Хрватске: у обе државе посебна судска власт има једино уставно овлашћење да проверавањем сагласности свих аката јавне власти са уставом утврђује конкретно значење, односно смисао уставних норми, и тако обезбеђује прави приоритет устава над законима и свим другим прописима (Вучетић 2004: 13).

Уставни суд Хрватске првенствено „одлучује о сагласности закона са Уставом”, „о сагласности других прописа са Уставом и законом”, односно „може оцењивати уставност и закона, и уставност и законитост других прописа који су престали да важе” (Устав Републике Хрватске, члан 125 став 1 тачка 1-3) (што се зове нормативна контрола или поступак оцене уставности и законитости); надаље, „одлучује поводом уставних тужби против појединачних одлука државних тела, тела јединица локалне и подручне (регионалне) самоуправе, односно правних лица са јавним овлашћењима кад су тим одлукама повређена људска права и основне слободе, као и право на локалну и подручну (регионалну) самоуправу" (Устав Републике Хрватске, члан 125 став 1 тачка 4). У српској правној терминологији ови правни инструменти се зову уставне жалбе. Што се тиче могућих исхода поступака, у току нормативне контроле, у случају утврђивања несагласности закона и других прописа са Уставом и/или законима суд 
може да укине цео пропис или поједине његове делове, или може поништити предмет оцене уставности и законитости in toto или in parte, имајући у виду посебну тежину повреде Устава, закона, односно интереса правне сигурности: „,ако се њима вређају људска права и основне слободе зајемчене Уставом; ако се њима појединци, групе или удружења неосновано стављају у повољнији или неповољнији положај” (Уставни закон о Уставном суду Републике Хрватске, члан 55). ${ }^{16}$ Како укинут, тако и поништен пропис престаје да даље производи правне последице, али у случају поништавања уклањају се и све до тада произведене правне последице, то јест, као да пропис није ни постојао у правном поретку.

Приликом одлучивања по уставној тужби Уставни суд може да усваја тужбу и да укида оспорени акт у целости или делимично (само неке од одредаба) којим је повређено неко уставно право; а у случају доношења новог акта уместо укинутог надлежан орган је дужан да поштује правно становиште и евентуалне инструкције суда. Друга је могућност да суд одбија уставну тужбу као неосновану (Уставни закон о Уставном суду Републике Хрватске, члан 73-77). У овим процесима суд испитује само оне повреде уставних права које су истакнуте у уставној тужби, или другим речима, подносилац треба да наведе уставно правно релевантне разлоге повреде (одлука Уставног суда Републике Хрватске под бр. U-III-540/1999 од 17. 05. 2000). Суд не разматра случајеве када се не ради о повреди уставног права, него неког другог права материјалног или процесног карактера (Уставни закон о Уставном суду Републике Хрватске, члан 71 став 1-2). У овом контексту уставно право представља Уставом зајамчено људско право или слободу, односно право на локалну и подручну (регионалну) самоуправу (Уставни закон о Уставном суду Републике Хрватске, члан 62 став 1). Али свака повреда Устава не представља истовремено и основ за усвајање уставне тужбе: повреда права треба да буде таквог значаја и интензитета који оправдава оцену суда о постојању повреде уставног права подносиоца уставне тужбе (одлука Уставног суда Републике Хрватске под бр. U-III-2432/2008 од 07. 10. 2009).

Уколико се погледају бројке поднетих уставних тужби и захтева/предлога за нормативну контролу почев од 2000. године, то јест у периоду који представља временски оквир овог истраживања, може се констатовати континуиран раст како у броју поступака нормативне контролне, тако и по уставним тужбама, али процентуално нема значајне разлике у дистрибуцији предмета једне, односно друге врсте поступака у односу на статистику периода између 1990. и 1999. године. ${ }^{17}$ Доминација случајева поводом уставних тужби у раду Уставног суда логична је последица универзалног карактера овог специјалног правног

\footnotetext{
${ }^{16}$ Ustavni zakon o Ustavnom sudu Republike Hrvatske, Narodne novine, br. 99/99, 29/02, 49/2002 prečišćen tekst.

${ }^{17}$ Примљени предмети у периоду од 1990. до 30. 06. 2020. https://www.usud.hr/sites/default/files/ dokumenti/Pregled_primljenih_predmeta_u_razdoblju_od_1990._do_30._lipnja_2020.pdf; Решени предмети у периоду од 1990. до 30. 06. 2020. https://www.usud.hr/sites/default/files/dokumenti/ Pregled_rijesenih_predmeta_u_razdoblju_od_1990._do_30._lipnja_2020.pdf
} 
лека који свако може поднети Уставном суду „,ако сматра да му је појединачним актом ... повређено људско право или основна слобода...” (Уставни закон о Уставном суду Републике Хрватске, члан 62). С друге стране, интересантно је да у предметима пред Уставним судом Хрватске у области мањинских права може да се нађе доста више предлога за нормативном контролом неког закона или општег правног акта ниже правне снаге, него уставних тужби.

Од скоро више од сто хиљада решених предмета у последњих двадесет година само неколико десетина се бави (наводном) повредом мањинских права у Хрватској (у складу са резултатима истраживања аутора које је спроведено анализирањем случајева Уставног суда Хрватске, који су доступни на службеној веб страници суда). ${ }^{18}$ На пример у Мађарској проценат предмета ове врсте је испод $1 \%$ у односу на укупан број предмета у последње три деценије (Nagy 2019: 86). У Хрватској, 38 одлука донетих у 51 предмету (у четири случаја Уставни суд је спојио предмете ради заједничког одлучивања у вези преференцијалног представљања припадника националних мањина у представничким телима) претежно су резултат нормативних контрола. У 20 оцена уставности закона и шест оцена законитости правних аката ниже правне снаге Уставни суд је поништио одредбе закона, односно другог правног прописа у осам случајева, док је у свим другим поступцима одбацио или није прихватио предлог. Три одлуке су донете поводом надзора над законитошћу избора, једна одлука поводом надзора над уставношћу и законитошћу државног референдума када је суд утврдио да референдумско питање није у складу са Уставом, а анализирано је још осам поступака по уставној тужби у којима су уставне тужбе у свим случајевима одбијане као неосноване. Важно је напоменути да су приликом селекције случајева који се детерминишу као случајеви у вези мањинских права у уставносудској пракси Хрватске изабрани само они предмети код којих постоји јасна мотивација да се штити право националне мањине или право већинског народа у односу на друге етничке заједнице. Оне судске одлуке које на неки начин могу имати додирне тачке са мањинским правима (на пример, универзално људско право на образовање), али нису првенствено усмерене ка заштити неког конкретног права националне мањине (на пример, право на образовање на матерњем језику, то јест на језику националне мањине), нису анализирани.

Чињеница да упоређујући са бројевима у генералној статистици међу предметима у вези са мањинским правима има значајно више захтева/предлога за оцену уставности и законитости него уставне жалбе по правилу рефлектује логично понашање припадника мањинских заједница не само у Хрватској, него и уопштено. Страх од евентуалне репресије, непознавање својих права, као и механизма за њихово остваривање су само неки од могућих разлога зашто припадници мањина не траже правну заштиту пред Уставним судом. Иначе у већини анализираних предмета подносиоци уставних тужби су били правници, односно запослени у јавном сектору који су већ на основу своје професије познаваоци основних људских, а и мањинских права, а који су у конкретним

\footnotetext{
18 За уставносудску праксу у Хрватској посетите https://sljeme.usud.hr/usud/praksaw.nsf.
} 
случајевима тврдили да супротно закону њихова национална припадност као основ за позитивну дискриминацију није била узета у обзир приликом избора, односно запошљавања (одлуке Уставног суда Републике Хрватске под бр. U-III-4681/2008 од 30. 06. 2010, U-III-4079/2010 од 17. 11. 2010, под бр. U-III-5760/2008 од 17. 11. 2010, под бр. U-III-2989/2010 од 31. 05. 2012, под бр. U-III-1286/2012 од 11. 12. 2014, под бр. U-III-1897/2013 од 05. 03. 2015).

У погледу тематике предмети су разноврсни: 1) пропорционална заступљеност у јавној управи и правосуђу, 2) преференцијално представљање у представничким телима и двоструко право гласа припадника мањинских заједница приликом избора ових тела, 3) питања у вези са телима културне аутономије националних мањина и 4) службена употреба матерњег језика (регулисање службеног статуса мањинског језика како на локалном, тако на регионалном нивоу, визуелна употреба језика на таблама са називима градова, улица, тргова, и на печатима, двојезичност јавних исправа). У следећем поглављу бавимо се случајевима из ове последње групе у циљу да нађемо одговор на питања: да ли је Уставни суд доследно протумачио права националних мањина за службену употребу матерњег језика у разним поступцима; да ли је поступао заштитнички према свим мањинама на исти начин, и најзад, да ли је заснивао своје одлуке на слову и/или на духу устава.

\section{Уставносудска пракса у области службене употребе мањинских језика - одабрани случајеви}

Удруга хрватских лијечника драговољаца 1990-1991. је предложила оцену уставности члана 4-20. Закона о употреби језика, то јест целокупне Главе 2 Закона о употреби језика, односно члана 10 Уставног закона о правима мањина (у два посебна предлога) у вези са слободом служења матерњим језиком приватно и јавно, односно слободом истицања ознака, натписа и других информација на мањинском језику јер наведене одредбе нису у складу чланом 16 Устава Хрватске који гласи: „Слободе и права могу се ограничити само законом да би се заштитила слобода и права других људи те правни поредак, јавни морал и здравље." Према подносиоцу предлога наводно неуставним законским одредбама нису прописана никаква ограничења за припаднике националне мањине у вези са употребом језика да би се заштитила права других лица на употребу свог језика. Уставни суд је ипак одбацио оба предлога, јер конкретни разлози за покретање нормативне контроле морају бити изнесени на разумљив, прецизан начин да би суд могао одлучити о бити ствари, што у овим поступцима није било учињено (одлука Уставног суда Републике Хрватске под бр. U-I-1000/2013 од 19. 06. 2018. и под бр. U-I-1003/2013 од 19. 06. 2018).

Уставносудска пракса Хрватске у области језичких права мањина ипак није толико једноставна као у претходном примеру. У оквиру овог поглавља детаљно се представљају две важне одлуке које могу да се сматрају каменом темељцем уставносудске праске у области одређивања основних уставних вред- 
ности хрватског друштва, односно један мање познат случај који ипак лепо илуструје приступ суда политички осетљивим темама. Наравно, има још поступака у којима је Уставни суд одлучио о језичким правима мањина, али нису толико релевантни за остваривање права припадника нових мањина, тачније српске мањинске заједнице. На пример, Талијанска унија са седиштем у Ријеци је оспоравала поједине одредбе Закона о подручјима жупанија, градова и општина у Републици Хрватској јер исте не садрже називе неких локалних самоуправа и на италијанском језику, само на хрватском. Уставни суд је обратио пажњу подносиоца предлога на нормативну контролу да су локалне самоуправе овлашћене да својим статутом уведу мањински језик у службену употребу, чак иако нису испуњени законски услови у погледу броја мањинске популације у датом граду, општини, и у складу са тако добијеним статусом језика, сви јавни натписи, укључујући и назив општине, односно града биће истакнути и на службеном, мањинском језику, у конкретном случају на италијанском (одлука Уставног суда Републике Хрватске под бр. U-I-1682/2003 од 26. 10. 2005). На крају, суд није прихватио предлог за покретање поступка нормативне контроле. Други предмет сличан овом садржи обрнут захтев. Заједница хрватских удруга у Истри је поднела предлог за оцену уставности и законитости Одлуке о именовању и преименовању улица и тргова на подручју насеља Бале број: O. U. 3/3-94 од 14. септембра 1994. године. „Извршењем наведене Одлуке предлагатељица сматра да је повређен члан 12 Устава који прописује да је у Републици Хрватској у службеној употреби хрватски језик и латинично писмо јер налази да се претежно италијанским називима улица избегава употреба хрватског језика. Сматра да оспорена Одлука нема довољну заступљеност заслужних личности већинског народа у називљу улица те да је у њој одсутан хрватски језик као службени језик Републике Хрватске, односно да се не поштују правила хрватске граматике и правописа“ (тачка 2 одлуке Уставног суда Републике Хрватске под бр. U-III-2432/2008 од 07. 10. 2009). Уставни суд је одлучио да је предлог неоснован: с једне стране, Статут Бале предвиђа равноправну службену употребу хрватског и италијанског језика и латиничног писма, односно гарантује истицање назива улица, тргова, места и других географских локалитета двојезично, с друге стране, исправљање евентуалних граматичких грешака или пропуста спада у надлежност управе, а не Уставног суда.

Табела 1: Приказ случајева пред Уставним судом Хрватске у области службене употребе мањинских језика (саставила је аутор)

\begin{tabular}{|l|l|l|l|l|}
\hline \multicolumn{1}{|c|}{$\begin{array}{c}\text { број и датум } \\
\text { одлуке }\end{array}$} & \multicolumn{1}{|c|}{ врста поступка } & \multicolumn{1}{|c|}{$\begin{array}{c}\text { подносилац - } \\
\text { предлагач }\end{array}$} & \multicolumn{1}{c|}{ одлука } \\
\hline $\begin{array}{l}\text { U-I-847/2001 } \\
\text { 09. 03. } 2005 .\end{array}$ & $\begin{array}{l}\text { оцена уставности } \\
\text { закона }\end{array}$ & $\begin{array}{l}\text { Хрватска чиста } \\
\text { странка права }\end{array}$ & $\begin{array}{l}\text { увођење мањинског језика и писма } \\
\text { у службену употребу на нивоу } \\
\text { жупанија }\end{array}$ & $\begin{array}{l}\text { решење о } \\
\text { неприхватању } \\
\text { предлога }\end{array}$ \\
\hline $\begin{array}{l}\text { U-II-425/2002 } \\
16.01 .2008 .\end{array}$ & $\begin{array}{l}\text { оцена уставности/ } \\
\text { законитости } \\
\text { статута }\end{array}$ & $\begin{array}{l}\text { приватна лица из } \\
\text { Загреба }\end{array}$ & $\begin{array}{l}\text { уређивање употребе језика на нивоу } \\
\text { жупаније }\end{array}$ & $\begin{array}{l}\text { решење о } \\
\text { неприхватању } \\
\text { предлога }\end{array}$ \\
\hline
\end{tabular}




\begin{tabular}{|c|c|c|c|c|}
\hline $\begin{array}{l}\text { U-II-2648/2002 } \\
\text { 29. 09. 2010. }\end{array}$ & $\begin{array}{l}\text { оцена уставности/ } \\
\text { законитости } \\
\text { одлуке }\end{array}$ & $\begin{array}{l}\text { Заједница } \\
\text { хрватских удруга у } \\
\text { Истри }\end{array}$ & $\begin{array}{l}\text { сувише назива улица на } \\
\text { италијанском језику, уместо назива } \\
\text { на хрватском }\end{array}$ & $\begin{array}{l}\text { решење о } \\
\text { неприхватању } \\
\text { предлога } \\
\end{array}$ \\
\hline $\begin{array}{l}\text { U-I-1682/2003 } \\
26.10 .2005 .\end{array}$ & $\begin{array}{l}\text { оцена уставности } \\
\text { закона }\end{array}$ & $\begin{array}{l}\text { Талијанска унија са } \\
\text { седиштем у Ријеци }\end{array}$ & $\begin{array}{l}\text { називи градова и насеља су наведени } \\
\text { у закону искључиво на хрватском } \\
\text { језику }\end{array}$ & $\begin{array}{l}\text { решење о } \\
\text { неприхватању } \\
\text { предлога } \\
\end{array}$ \\
\hline $\begin{array}{l}\text { U-III-4856/2004 } \\
12.03 .2007 .\end{array}$ & уставна тужба & $\begin{array}{l}\text { приватно лице из } \\
\text { Ријеке }\end{array}$ & $\begin{array}{l}\text { одбијање личне карте (и) на српском } \\
\text { језику и ћириличком писму }\end{array}$ & $\begin{array}{l}\text { одлука о } \\
\text { одбијању уставне } \\
\text { тужбе }\end{array}$ \\
\hline $\begin{array}{l}\text { U-I-1000/2013 } \\
\text { 19. 06. } 2018 .\end{array}$ & $\begin{array}{l}\text { оцена уставности } \\
\text { закона }\end{array}$ & $\begin{array}{l}\text { Удруга хрватских } \\
\text { лијечника } \\
\text { драговољаца 1990.- } \\
1991 .\end{array}$ & $\begin{array}{l}\text { нису успостављене границе } \\
\text { службене употребе мањинског } \\
\text { језика у Уставном закону о правима } \\
\text { мањина }\end{array}$ & $\begin{array}{l}\text { решење о } \\
\text { одбацивању } \\
\text { предлога }\end{array}$ \\
\hline $\begin{array}{l}\text { U-I-1003/2013 } \\
\text { 19. 06. } 2018 .\end{array}$ & $\begin{array}{l}\text { оцена уставности } \\
\text { закона }\end{array}$ & $\begin{array}{l}\text { Удруга хрватских } \\
\text { лијечника } \\
\text { драговољаца 1990.- } \\
1991 .\end{array}$ & $\begin{array}{l}\text { нису успостављене границе } \\
\text { службене употребе мањинског језика } \\
\text { у Закону о употреби мањинских } \\
\text { језика }\end{array}$ & $\begin{array}{l}\text { решење о } \\
\text { одбацивању } \\
\text { предлога }\end{array}$ \\
\hline $\begin{array}{l}\text { U-II-6110/2013 } \\
\text { 12. } 08.2014 .\end{array}$ & $\begin{array}{l}\text { оцена уставности/ } \\
\text { законитости } \\
\text { статута } \\
\end{array}$ & $\begin{array}{l}\text { Влада Републике } \\
\text { Хрватске }\end{array}$ & $\begin{array}{l}\text { изузимање подручја Града Вуковара } \\
\text { од примене Закона о употреби } \\
\text { мањинских језика }\end{array}$ & $\begin{array}{l}\text { одлука о укидању } \\
\text { одредбе }\end{array}$ \\
\hline $\begin{array}{l}\text { U-VIIR-4640/2014 } \\
\text { 12. } 08.2014 .\end{array}$ & $\begin{array}{l}\text { оцена уставности } \\
\text { референдумског } \\
\text { питања }\end{array}$ & Хрватски сабор & $\begin{array}{l}\text { пооштравање цензуса за увођење } \\
\text { мањинског језика у службену } \\
\text { употребу }\end{array}$ & $\begin{array}{l}\text { референдумско } \\
\text { питање је } \\
\text { неуставно } \\
\end{array}$ \\
\hline \multirow[b]{2}{*}{$\begin{array}{l}\text { U-II-1818/2016 } \\
02.07 .2019 .\end{array}$} & \multirow[b]{2}{*}{$\begin{array}{l}\text { оцена уставности/ } \\
\text { законитости } \\
\text { статута }\end{array}$} & \multirow{2}{*}{$\begin{array}{l}\text { Хрватски сабор, } \\
\text { Одбор за људска } \\
\text { права и права } \\
\text { националних } \\
\text { мањина }\end{array}$} & \multirow[b]{2}{*}{$\begin{array}{l}\text { регулисање службене употребе } \\
\text { језика у Граду Вуковару }\end{array}$} & одбијање захтева \\
\hline & & & & $\begin{array}{l}\text { одлука о укидању } \\
\text { одредбе }\end{array}$ \\
\hline
\end{tabular}

\section{Лична карта (и) на српском језику и ћириличком писму}

Полицијска управа приморске-горанске жупаније је одбила захтев подносиоца уставне тужбе из Ријеке да изда двојезичну личну карту, односно тројезичну: на хрватском и енглеском језику и латиничним писмом, односно на српском језику и ћириличком писму. Подносилац уставне тужбе затим је уложио жалбу на решење полицијске управе Министарству унутрашњих послова Републике Хрватске. С обзиром да Министарство уопште није поступило по жалби, поднео је тужбу Управном суду Хрватске због ћутања управе. На основу налога Управног суда Министарство је донело другостепено решење којим је потврдило првостепену одлуку полицијске управе, то јест поново одбило захтев за издавање двојезичне/тројезичне личне карте, зато је подносилац уставне тужбе проширио тужбени захтев Управном суду и на садржину другостепеног решења. Уставносудски поступак у овом случају се води против пресуде Управног суда Хрватске бр. Us-9774/03-11 од 14. октобра 2004. године којом је одбијена тужба против другостепеног решења Министарства бр. 51101-72-UP/II-943/1-03 од 3. октобра 2003. године.

Подносилац уставне тужбе се позивао на своје право из члана 9 става 2 Уставног закона о правима мањина којим се прописује да се образац личне карте штампа и попуњава и на језику и писму припадника националне мањине. Према његовим наводима, право на двојезичну исправу „припада сваком припаднику националне мањине који то затражи, било где на подручју Репу- 
блике Хрватске и без обзира на то је ли за подручје јединице локалне самоуправе у којој има пребивалиште и у којој тражи издавање особне исказнице (личне карте - аутор), прописана равноправна службена употреба мањинског језика и писма" (тачка 2 одлуке Уставног суда Републике Хрватске под бр. UIII-4856/2004 од 12. 03. 2007). Подносилац је образложио свој став чињеницом да Уставни закон у одредби о праву на двојезичну личну карту (то јест у члану 9, став 2) уопште не спомиње службени статус мањинског језика, нити се позива на други закон.

У Уставном закону двојезична лична карта као таква је посебно наведена. Нема речи о другим јавним исправама, односно обрасцима у датој законској одредби, нити има потребе за даљом законском разрадом за остваривање овог права, што је иначе пример у вези са правом на лично име на матерњем језику које је регулисано у истој одредби. Према Уставном закону, лично име се може користити на матерњем језику само у складу са прописима Републике Хрватске (члан 9 став 1 Уставног закона). С друге стране према материјалном закону о личној карти основно је правило да се образац штампа на хрватском и енглеском језику и латиничном писмом, а попуњава се само хрватским језиком. Када је то утврђено посебним законом или међународним уговором, образац за конкретно лице - припадника националне мањине штампа се и на мањинском, односно попуњава се поред хрватског језика и језиком и писмом националне мањине (Закон о особној исказници, члан 8). ${ }^{19}$ Закон о употреби мањинског језика који има статус посебног закона у конкретном примеру, предвиђа да уколико је језик мањине у равноправној службеној употреби у општини, граду или жупанији, јавне исправе се издају двојезично или вишејезично, односно обрасци за службене сврхе такође се штампају на више језика (члан 9 став 1). Слично решење се налази и у билатералном уговору између Србије и Хрватске о узајамној заштити националних мањина: „стране уговорнице се обавезују да ће осигурати на подручјима где живе припадници националне мањине, а у складу са унутрашњим законодавством и усвојеним међународно-правним стандардима, службену употребу језика и писма националне мањине, и то: ... код издавања јавних исправа, потврда и уверења; ... у коришћењу двојезичних образаца ... државних тела" (Закон о ратификацији Споразума између Србије и Црне Горе и Републике Хрватске..., члан 6 став 2 тачка 4, 6). ${ }^{20}$

С обзиром да Уставни закон безусловно признаје право на двојезичну личну карту на територији целе државе, с једне стране, а Закон о употреби језика везује остваривање овог права за службени статус датог мањинског језика, с друге стране, овај случај је типична колизија између два закона. Ипак Уставни суд није се упустио у дубљу анализу; насупрот томе предметну одредбу тумачио је заједно са чланом 12 став 3 Уставног закона којим се предвиђа да

\footnotetext{
${ }^{19}$ Zakon o osobnoj iskaznici, Narodne novine, br. 11/2002.

20 Закон о ратификацији споразума између Србије и Црне Горе и Републике Хрватске о заштити права српске и црногорске мањине у Републици Хрватској и хрватске мањине у Србији и Црној Гори, Службени лист СЦГ-Међународни уговори, број 3/2005.
} 
се детаљни елементи и начин службене употребе мањинских језика регулишу Законом о употреби језика и писма националних мањина, независно од тога да се у конкретном примеру Уставни закон не позива на одредбе овог прописа. „Фактички дао је предност секторском закону у односу на Уставни закон када је одбио уставну тужбу (одлука Уставног суда Републике Хрватске под бр. UIII-4856/2004 од 12. 03. 2007), не узимајући у обзир да је на овај начин ускратио коришћење једног језичког права" (Беретка 2019: 271).

На основу максиме lex specialis derogat legi generali ${ }^{21}$ специјални закон (било Закон о употреби мањинских језика, било Закон о личној карти) би требало да се примењује - што одговара и приступу Уставног суда овом питању. Али да ли је праведно применити пропис, било општег, било посебног карактера, који садржи мањи обим права? Ово питање је посебно интересантно у светлу досадашње праксе Уставног суда, када је, одлучујући о једном изборном спору, донео обрнуту одлуку. ${ }^{22}$ Према образложењу суда Уставним законом се прописује „онај минимум права који припадници националних мањина морају имати када говоримо о њиховој заступљености у представничким телима јединица локалне и подручне (регионалне) самоуправе (удео од 5\% у становништву јединице или право прописано статутом јединице), док се посебним законом, у овом случају Законом о локалним изборима [...] то право може и проширити" (тачка 3 одлуке Уставног суда Републике Хрватске под бр. U-VIIA-3004/2013 од 26. 05. 2013). У анализираном случају о двојезичним личним картама ситуација је баш обрнута: Уставни закон, као lex generalis садржи већи обим права у односу на lex specialis.

„Може се закључити да према уставносудској пракси Уставни закон представља lex generalis у случају конфликта са неким специјалним прописом, независно од тога да ли садржи већа права за националне мањине у односу на lex specialis (секторски закон) или не" (Беретка 2019: 272). Уставни суд уопште није разматрао могућност издавања личне карте и на српском језику и ћириличком писму на подручју локалне самоуправе у којем српски језик нема статус равноправног службеног језика, јер та није регулисана специјалним законом; иако приликом сваке недоумице у вези са тумачењем одредаба Уставног закона и других аката у области мањинских права суд би требало да се руководи сврхом поштовања припадника националних мањина и хрватског народа, развијања разумевања, солидарности, сношљивости и дијалога међу њима (Уставни закон о правима националних мањина, члан 8).

У хипотетичком случају усвајања уставне тужбе одлуком Уставног суда би се створио потенцијал за издавање личне карте и на српском језику и ћири-

\footnotetext{
${ }^{21}$ Посебан (специјални) закон укида општи закон.

22 У Бродско-посавској жупанији припадници српске националне мањине нису остварили одговарајућу заступљеност у жупанијској скупштини, јер је Државна изборна комисија засновала своју одлуку на члану 20. Уставног закона, уместо примене члана 104 став 1 Закона о локалним изборима. Законом о локалним изборима гарантовало би се једно посланичко место за српску заједницу, док према Уставном закону (који закон су применили у конкретном случају) Срби не би добили ниједан мандат (одлука Уставног суда Републике Хрватске под бр. U-VII-3122/2013 од 04. 06. 2013).
} 
личком писму на целој територији Хрватске, што, према прикривеном образложењу суда, није био циљ законодавца. Толико екстензивно тумачење намере законодавца може да се сматра чак и судским активизмом у предметном примеру: „Судски активизам настаје онда кад се судови више не брину само за пресуђивање правних спорова, већ им је циљ стварање друштвене политике, чиме они захвате много више људи и интереса неголи је то случај у решавању појединачног случаја" (Вас̌ić 2008: 106).

С друге стране, подносилац уставне тужбе је заснивао своју тужбу на повреди уставних права гарантованих чланом 14 став 1 (забрана дискриминације), члана 14 став 2 (једнакост пред законом), члана 15 став 4 (слободно служење мањинским језиком и писмом), члана 29 став 1 (право на правично суђење) и члана 32 Устава Републике Хрватске (слобода кретања и бирања боравишта) која права, према анализи Уставног суда нису била повређена одбијањем издавања двојезичне личне карте; а како је већ наведено у претходном поглављу, суд испитује евентуалну повреду права само у оквиру разлога експлицитно истакнутих у уставној тужби. Подносилац уставне тужбе би вероватно имао већу шансу „за победу“ ако би се позвао на повреду правне сигурности због јасне колизије између прописа у конкретном случају.

\section{Референдумско питање о службеној употреби мањинских језика}

Грађанска иницијатива „Стожер за обрану хрватског Вуковара“ је 13. децембра 2013. године поднела захтев Хрватском сабору, заведен под ур. бројем: 361-13-03-1787, класа: 014-01/13-01/06, за расписивање референдума са следећем питањем: „Јесте ли за то да се чланак 12 ставак 1 Уставног закона о правима националних мањина ('Народне новине', бр. 155/02, 47/10, 80/10. и 93/11) мења тако да гласи: 'Равноправна службена употреба језика и писма којим се служе припадници националне мањине остварује се на подручју јединице локалне самоуправе, државне управе и правосуђа, када припадници поједине националне мањине чине најмање половину становника такве јединице’?“ На основу захтева Хрватског сабора за утврђивање уставности садржаја питања, односно испуњености уставних претпоставки за расписивање референдума Уставни суд је утврдио да иако су услови испуњени, ово питање није у складу са Уставом, и зато није ни допустио расписивање референдума (одлука Уставног суда Републике Хрватске под бр. U-VIIR-4640/2014 од 12. 08. 2014).

Уставни суд је констатовао да је предложена допуна законске норме неправилно формулисана, јер се у члану 12 став 1 Уставног закона о правима мањина говори о просторној употреби мањинских језика, а државна управа, односно правосуђе нису административне-територијалне јединице. Али суд се није упуштао у даљу интерпретацију овог дела питања, будући да је пооштравање цензуса са једне трећине на половину само по себи супротно Уставу.

У периоду важења претходног закона о правима мањина (1991-2002) био је на снази строжи услов у погледу прага за увођење једног мањинског језика у 
службену употребу. Уместо тренутно применљиве једне трећине, у општинама (а не и у градовима) мањинска заједница је требало да чини најмање половину локалног становништва да би се њен језик увео у службену употребу (Уставни закон о људским правима и слободама и о правима етничких и националних заједница или мањина у Републици Хрватској, члан 7 став 2). ${ }^{23}$ Међутим, то не значи и могућност повраћаја на старо стање.

С обзиром да Устав не одређује никакве претпоставке за увођење мањинских језика у службену употребу у јединицама локалне самоуправе, него препушта исто законодавцу, Уставни суд није могао да нађе јасан, недвосмислен правни основ у Уставу због чега би морао да одбије расписивање референдума по наведеном питању. Зато је, насупрот позивању на експлицитно уставно ограничење, суд нагласио да треба истражити имплицитна обележја једног демократског друштва која се огледају у плурализму, толеранцији, слободоумљу, изражавању етничке припадности и истицању мањинске свести (тачка 10.2 одлуке Уставног суда Републике Хрватске под бр. U-VIIR-4640/2014 од 12. 08. 2014). „Индивидуално право припадника националних мањина на слободу служења својим језиком и писмом ... од хрватског народа као већинског захтева толеранцију и разумевање, тражи стално подсећање на вредности Устава и на границе допуштеног понашања према мањинама, које поставља Устав” (тачка 13). Зато из непостојања писаних правила суд није могао извести ,закључак о априорној и безусловној допуштености повећања прага за службену употребу језика и писма националних мањина. Устав у том питању поставља захтеве који произлазе из демократског друштва утемељеног на владавини права“ (тачка 10). Дакле, било каква промена од утицаја на остваривање језичких права националних мањина, укључујући и повећање прага за увођење мањинског језика у службену употребу, треба да буде разумно оправдано, што према интерпретацији суда обухвата следеће елементе: 1) да промена има јасно изражен легитиман циљ у општем интересу, 2) да је нужна (у смислу да је сразмерна легитимном циљу) у условима једног демократског друштва, и 3) мора да постоји ургентна друштвена потреба за променама у датој области (тачка 14).

Уставносудска одлука о референдумском питању је од изузетне важности због више разлога: с једне стране, одређује основне, универзалне уставне вредности од којих се не може одрећи, односно одступити, с друге стране, заснива се на духу Устава, уместо највише фаворизованог начина тумачења устава: текстуализма. Ипак ова одлука има још једну битну димензију, и то политичку. Иако се референдумско питање односило на измену Уставног закона који се једнако примењује на све националне мањине у Хрватској, није тајна да је било мотивисано животним чињеницама и фактичним околностима које владају Вуковаром. „Ћирилично писмо у Граду Вуковару већина његових грађана још увек 'доживљава као симбол страдања', да би на крају циљ предложеног ре-

\footnotetext{
${ }^{23}$ Ustavni zakon o ljudskim pravima i slobodama i o pravima etničkih i nacionalnih zajednica ili manjina u Republici Hrvatskoj, Narodne novine, br. 65/91, 27/92, 34/92. - pročišćeni tekst, 51/00, 105/00. - pročišćeni tekst.
} 
ферендума објаснио правом грађана да „одлуче о томе што желе са Вуковаром и каква правила морају владати у Вуковару али и цијелој РX“ како је наведено у тачки 28 одлуке у којој је суд цитирао део захтева Организацијског одбора. Према схватању Уставног суда нема разлога сумњати да су све радње потписника иницијативе, односно Организацијског одбора предузете у доброј вери, у циљу решавања неких проблема као резултата ратних збивања путем референдума. Али напад на једно писмо, у овом случају ћириличко, као универзалну цивилизацијску тековину човечанства која одређује сам идентитет хрватске уставне државе дубоко је узнемирујући, чак ирационалан чин. Читајући други део одлуке, имамо осећај као да Уставни суд покушава да оправдава своју одлуку, односно да изрази латентну солидарност са иницијаторима референдума: „Уставни суд верује да су и Организацијски одбор, и грађани Вуковара, као и сви потписници иницијативе, искрено одани идеалима отелотвореним у хрватском Уставу и да никада не би пристали на поступке који би Уставу били противни, колико год понекад било тешко прихватити импликације које произлазе из неких његових захтева" (тачка 29 одлуке Уставног суда Републике Хрватске под бр. U-VIIR-4640/2014 од 12. 08. 2014).

У овом предмету Уставни суд је усвојио једно јако напредно гледиште што се тиче интерпретације уставних одредаба у области права мањина, иако су одлуку засенили споменути политички елементи образложења. „Решавање политичких спорова и сукоба применом права није могуће спровести у потпуности, без опасности да се ‘јуридизација политике' не изврне у 'политизацију уставног судства"” (Šarin 2015: 756).

\section{Употреба српског језика у Вуковару}

Последњи случај који је привукао пажњу политичке, стручне, а и лаичке јавности како у земљи, тако и у иностранству у јулу 2019. године био је одлука Уставног суда о укидању појединих одредаба Статутарне одлуке о остваривању равноправне службене употребе језика и писма српске националне мањине на подручју Града Вуковара, која је поред класичних језичких права морала да дотакне и нека сензибилна питања у процесу помирења између два народа.

Још 2013. године Влада Републике Хрватске поднела је захтев за нормативну контролу члана 22 Статутарне одлуке о изменама и допунама Статута Града Вуковара којим се цело подручје Вуковара изузимало од употребе Закона о употреби језика и писма националних мањина у Хрватској. ${ }^{24}$ Иако је према резултатима пописа из 2011. године проценат српског локалног становништва износио више од једне трећине у Вуковару (Државни завод за статистику Хрватске 2013: 46-47), због чега је град по сили закона био у обавези да уводи српски језик и ћириличко писмо у равноправну службену употребу, то није

\footnotetext{
${ }^{24}$ Statutarna odluka o izmjenama i dopunama Statuta Grada Vukovara, Službeni vjesnik Grada Vukovara, br. 7/2013.
} 
учињено јер је „подручје Града Вуковара место посебног пијетета на жртву Домовинског рата" (члан 1 став 1 Статутарне одлуке о изменама и допунама Статута Града Вуковара); и све док се не испуне услови из члана 8 Уставног закона о правима националних мањина (члан 22 Статутарне одлуке о изменама и допунама Статута Града Вуковара), хрватски језик заједно са латиничким писмом ће остати једини језик у службеној употреби у граду. 2014. године Уставни суд је укинуо оспорени члан 22 Статутарне одлуке, експлицитно прихвативши становиште Владе које гласи да је одредба „у директној супротности с највишим вредностима Устава и уставним поретком Републике Хрватске и као таква не може егзистирати у демократској, уређеној правној држави“ (тачка 4 одлуке Уставног суда Републике Хрватске под бр. U-II-6110/2013 од 12. 08. 2014). Град Вуковар је добио рок од годину дана да уреди индивидуална права припадника националних мањина у области службене употребе језика и писма на својој територији, што је учињено у року. 2015. године Градско веће Града Вуковара је изменило Статут, односно Статутарну одлуку о остваривању равноправне службене употребе језика и писма српске националне мањине на подручју Града Вуковара, према налозима суда, против којих аката је Одбор за људска права и права националних мањина Хрватског сабора поднео захтев за оцену уставности и законитости 2016. године. Поступак је окончан у јулу 2019. године.

У овом другом поступку због директне супротности са члановима 8, 9 и 11 Закона о употреби језика и писма националних мањина, Уставни суд је укинуо члан 5 став 1 и 2 Статутарне одлуке о остваривању равноправне службене употребе језика у деловима који су условљавали остваривање права чланова Градског већа из реда српске националне мањине за добијање материјала седнице на свом језику и писму подношењем посебног захтева, односно обезбеђивањем наменских буџетских средстава, односно члан 6 став 1 због повезивања права грађана на преписе докумената на српском језику и ћирилици постојањем правног интереса. Члан 6 став 2 је укинут без позивања на конкретан правни основ, сматрајући се да „не постоји ниједан прихватљив разлог“ (тачка 27.2 одлуке Уставног суда Републике Хрватске, под бр. U-II-1818/2016 од 02. 07. $2019)$,због чега би исписивање текста печата и жигова истом величином слова на свим језицима у службеној употреби требало осигурати само када се за то стекну услови" (Беретка 2019: 284).

С друге стране, одржавањем члана 7 Статутарне одлуке о остваривању равноправне службене употребе језика на снази, који гласи: „[к]олективна права српске националне мањине на подручју Града Вуковара осигуравају се када се стекну услови из члана 61 став 3 Статута Града Вуковара", Уставни суд је поступао више као политичар. Градско веће Вуковара сваке године разматра достигнути степен разумевања, солидарности, сношљивости и дијалога међу припадницама хрватског народа и српске националне мањине у Вуковару и „доноси одлуку о могућности, односно потреби проширивања опсега осигураних индивидуалних права припадника српске националне мањине који живе у Граду Вуковару новим правима из каталога права предвиђаних законом о 
употреби језика и писма националних мањина у Републици Хрватској” (члан 61 став 3 Статута Града Вуковара, и члан 5 став 3 Статутарне одлуке о изменама и допунама Статута Града Вуковара). Према Уставном суду „не постоји разлог због којег би ову одредбу требало укинути“ (тачка 28.1 одлуке Уставног суда Републике Хрватске, под бр. U-II-1818/2016 од 02. 07. 2019), али истовремено ова одредба „не сме бити злоупотребљена на начин да представља пуко обећање права припадника националних мањина које се неће и провести“ (члан 22). Имајући у виду да се у оквиру овог рада првенствено бавимо језичким правима мањина, не анализирамо посебно како се Уставни суд снашао у овој специфичној политичкој реалности. Битно је једино напоменути да је уместо навођења конкретне уставне одредбе дао јако једноставан одговор, да ни садржај ни временски оквир оспорених ставова у вези колективних права Срба у Вуковару нису у несагласности са Уставом (тачка 20.3 и 20.4 одлуке Уставног суда Републике Хрватске, под бр. U-II-1818/2016 од 02. 07. 2019).

Овај случај је добио посебно место у последњем извештају Комитета експерата, у којем је комитет подсетио надлежне органе Хрватске на њихову обавезу на употребу ћириличког писма у администрацији, нарочито јер ћириличко писмо користе не само припадници српске, него и украјинске и русинске заједнице у овој области (Committee of Experts 2020: 8). „Јавни протести против увођења ћирилице у Вуковару упућују стога на нелегитимност мањинских одредаба у очима већине и пуно су више исказ досадашњег пропуста власти да хрватским грађанима и грађанкама објасне потребу и сврху мањинских права него израз колективне жеље за негирањем права припадника српске националне мањине. У заједници нарушених међуетничких односа треба тежити решењима која доприносе помирењу и поновној успостави нарушеног поверења, али не на терет позитивних законских прописа“" (Petričušić 2013: 37).

Нарочито у првом поступку у вези са употребом српског језика у Вуковару, Уставни суд се стварно трудио да нађе равнотежу између интереса већине и мањине, и истакао да прописивање права у складу са законом треба да одговара како животним чињеницама тако и фактичким околностима у Вуковару, што истовремено „уважава потребе већинског хрватског народа које извиру из још увек живих последица великосрпске агресије почетком 90-их година", а и „потребу праведног и правилног третмана српске националне мањине” (тачка 9 одлуке Уставног суда Републике Хрватске под бр. U-II-6110/2013 од 12. 08. 2014). С друге стране, такво балансирање и политичка коректност доводи у питање начелни став Уставног суда о нужном уздржавању од бављења политиком: да суд „није учесник политичких расправа нити је арбитар у решавању политичких спорова који настају у хрватском друштву. За решавање насталих проблема не постоји друго средство осим свестраног политичког дијалога вођеног у доброј вери, ма како неугодан би тај дијалог понекад могао бити" (тачка 33 одлуке Уставног суда Републике Хрватске под бр. U-VIIR-4640/2014 од 12. 08. 2014). 
Закључци

Првобитно питање које смо поставили у овом раду се односи на начин приступа Уставног суда Хрватске језичким правима мањина у области службене комуникације: да ли је суд био доследан; уз помоћ које технике је тумачио релевантне одредбе устава; да ли је узео у обзир и дух устава, а не само његов текст; колико је актуелна политика утицала на одлучивање, итд. На основу анализе неколико предмета из уставносудске праксе, може се закључити да је понекад суд стварно покушао да заштити језичка права мањина, чак и без конкретног уставног основа, заснивајући своје одлуке на неким генералним вредностима како државе, тако и највишег правног акта. „Индивидуално 'право на слободу' служења својим језиком и писмом ... нема ни привремени, ни транзицијски карактер. Оно чини бит идентитета сваког народа и универзалне је нарави. Припада у најсветлије цивилизацијске тековине човечанства", како се налази у одлуци о референдумском питању (тачка 13 одлуке Уставног суда Републике Хрватске под бр. U-VIIR-4640/2014 од 12. 08. 2014). Али било би сувише идеалистично рећи да је суд увек одлучио у корист мањина, односно мањинских права. Довољно се подсетити на његов став у вези са односом Уставног закона о правима мањина и других секторских закона; то јест, када су афирмативне одредбе Уставног закона често дерогиране специјалним законима који не штите довољно мањинска права.

С друге стране, Уставни суд је покушавао да ублажи своје напредне интерпретације образложењима која више имају политички, него правни карактер, изражавајући латентно саосећање противницима језичких права мањина. Према литератури поредак, постављен од стране Уставног суда, „који се правилно балансира између легитимних уставних интереса већине и мањине” представља део уставно-правног идентитета Хрватске (Toplak \& Gardašević 2017). Иако је овај став заузет поводом случаја о референдумском питању, може да се примењује и на случај Вуковара. Ипак приликом таквог балансирања прети опасност да суд противречи сам себи у вези са судском неутралношћу у политички надахнутим предметима, независно од тога да то на крају крајева није било од утицаја на коначну одлуку - макар кад се ради о праву на службену употребу матерњег језика националних мањина. Ситуација је сложенија у последњем примеру у вези са проширивањем колективних права српске националне заједнице у Вуковару, када Уставни суд није био толико заштитнички настројен, и одлуку је образложио у светлу актуелног политичког стања у граду, али то је већ једна друга прича. 


\section{Литература}

Andeva, M. \& Beretka, K. (2018) „The (Non)-Existing EU Standards in National Minority Protection as Prerequisites for Successful European Integration: The Case of Macedonia and Serbia“" in Thirteenth annual international academic conference on European Integration Europe and the Balkans. pp. 165-184. Skopje: University American College.

Andrássy, Gy. (2013) „A nyelvszabadságról es a nyelvszabadság jelentőségéről”, Létünk különszám: 7-19.

Bačić, A. (2008) „O sudskom aktivizmu ili o političkoj ulozi sudova“, Politička misao -Croatian political science review 35 (2): 94-114.

Bagdasarov, A. R. (2018) „O etnojezičnoj politici u socijalističkoj Jugoslaviji“, Filologija 71 (2): 25-60.

Beretka, K. (2019) „A nyelvi jogsértések szankcionálhatóságának tételes jogi és nemzetközi jogi dimenziói”. Tanulmányok 59 (2): 41-58.

Беретка, К. (2019) „Уставносудска пракса у Републици Хрватској у области заштите права националних мањина“ in Nemzet, közösség, kisebbség, identitás - Az alkotmánybíróságok védelmező szerepe ... стр. 265-294. Szeged: SZTE ÁJK NRTI.

Bugarski, R. (2004) „Language and Boundaries in the Yugoslav Context” in Language, Discourse and Borders in the Yugoslav Successor States. pp. 21-37. Bristol: Multilingual Matters.

Državni zavod za statistiku Republike Hrvatske (2013) Popis 2011 jer zemlje čine ljudiPopis stanovništva, kućanstava i stanova 2011 - Stanovništvo prema državljanstvu, narodnosti, vjeri i materinskom jeziku. Zagreb: Statistička izvešća.

Korhecz, T. (2013) „A hivatalos nyelvhasználat szabályozása Svájcban”, Létünk különszám: 92-112.

Kuntić, D. (2003) „Minority Rights in Croatia”, Croatian International Relations Review 9 (30-31): 33-39.

Medda-Windischer, R. (2017) „Old and New Minorities: Diversity Governance and Social Cohesion from the Perspective of Minority Rights", Acta Universitatis Sapientiae, European and Regional Studies 11 (1): 25-42.

Nagy, N. (2019) „'Nyelvében él a nemzet(iség)’ avagy a magyarországi nemzetiségek nyelvi jogainak alkotmánybírósági védelme“, Fundamentum 23 (3-4): 86-98.

Petričušić, A. (2013) „Ravnopravna službena uporaba jezika i pisma nacionalnih manjina: izvori domaćeg i međunarodnog prava", ZPR 2 (1): 11-39.

Radaković, M. \& Mikić, Lj. b.d. Priručnik o Ustavnom zakonu o pravima nacionalnih manjina. Zagreb: WYG savjetovanje d.o.o.

Радушки, Н. (2012) „Срби од конститутивног народа до националне мањине“, Сpnска политичка мисао 36 (2): 443-459.

Šarin, D. (2015) „Ustavni sud Republike Hrvatske kao institucionalni zaštitnik ljudskih prava i temeljnih sloboda“, Zbornik radova Pravnog fakulteta u Splitu 52 (3): 755-784. 
Committee of Experts. 2020. Report of the Committee of Experts presented to the Committee of Ministers of the Council of Europe in accordance with Article 16 of the Charter, Sixth Report. Croatia. Strasbourg, 10 March 2020. No. MIN-LANG (2019) 18.

Tatalović, S. (2006) „Nacionalne manjine i hrvatska demokracija“, Politička misao 43 (2):159-174.

Tatalović, S. b.d. „Ostvarivanje prava nacionalnih manjina u Republici Hrvatskoj i Europske integracije“. https://pravamanjina.rs/attachments/Tatalovic $\% 20-\% 20$ Zastita\%20manjina\%20u\%20Hrvatskoj.pdf

Теофиловић, П. (2020),Пракса уставног суда Словеније у области права националних мањина“ in Nemzet, közösség, kisebbség, identitás - Az alkotmánybíróságok védelmező szerepe ... стр. 216-264. Szeged: SZTE ÁJK NRTI.

Toplak, J. \& Gardašević, Đ. (2017) „Concepts of National and Constitutional Identity in Croatian Constitutional Law," Review of Central and East European Law 42 (4): 263-293. https://brill.com/view/journals/rela/42/4/article-p263_263. $\mathrm{xml}$ ?rskey $=\mathrm{xdebZf \& result}=2$

Вучетић, С. (2004) „Улога уставног суда у процесу транзиције у Србији“ у Уставни суд Србије - у сусрет новом уставу - Зборник радова - реферати. стр. 13-19. Београд: Уставни суд Србије.

\section{Уставносудске одлуке}

Одлука Уставног суда Републике Хрватске под бр. U-I-1029/2007 од 07. 04. 2010. Narodne novine, 47/10.

Одлука Уставног суда Републике Хрватске под бр. U-I-774/2000 од 20. 12. 2000, Narodne novine, $1 / 01$.

Одлука Уставног суда Републике Хрватске под бр. U-II-1818/2016 од 02. 07. 2019.

Одлука Уставног суда Републике Хрватске под бр. U-II-2648/2002 од 29. 09. 2010., Narodne novine, 118/10.

Одлука Уставног суда Републике Хрватске под бр. U-II-3224/2006.

Одлука Уставног суда Републике Хрватске под бр. U-II-6110/2013 од 12. 08. 2014.

Одлука Уставног суда Републике Хрватске под бр. U-III-2432/2008 од 07. 10. 2009.

Одлука Уставног суда Републике Хрватске под бр. U-III-4856/2004 од 12. 03. 2007.

Одлука Уставног суда Републике Хрватске под бр. U-III-540/1999 од 17. 05. 2000.

Одлука Уставног суда Републике Хрватске под бр. U-VII-3122/2013 од 04. 06. 2013, Narodne novine, 67/13.

Одлука Уставног суда Републике Хрватске под бр. U-VIIA-3004/2013 од 26. 05. 2013.

Одлука Уставног суда Републике Хрватске под бр. U-VIIR-4640/2014 од 12. 08. 2014, Narodne novine, 104/14. 


\section{Правни прописи}

Statutarna odluka o izmjenama i dopunama Statuta Grada Vukovara, Službeni vjesnik Grada Vukovara, br. 7/2013.

Statutarna odluka o izmjenama i dopunama Statuta Grada Vukovara, Službeni vjesnik Grada Vukovara, br. 7/15.

Statutarna odluka o ostvarivanju ravnopravne službene uporabe jezika i pisma srpske nacionalne manjine na području Grada Vukovara, Službeni vjesnik Grada Vukovara, br. $7 / 15$.

Ustav Republike Hrvatske, Narodne novine, br. 56/90, 135/97, 113/00, 28/01, 76/10, 5/14.

Ustav Republike Slovenije, Uradni list Republike Slovenije, št. 33/91-I, 42/97 - UZS68, 66/00 - UZ80, 24/03 - UZ3a, 47, 68, 69/04 - UZ14, 69/04 - UZ43, 69/04 - UZ50, 68/06 - UZ121,140,143, 47/13 - UZ148, 47/13 - UZ90,97,99 in 75/16 - UZ70a.

Устав Републике Србије, Службени гласник Републике Србије, бр. 98/2006.

Ustavni zakon o ljudskim pravima i slobodama i o pravima etničkih i nacionalnih zajednica ili manjina u Republici Hrvatskoj, Narodne novine, br. 65/91., 27/92., 34/92. - pročišćeni tekst, 51/00., 105/00. - pročišćeni tekst.

Ustavni zakon o pravima nacionalnih manjina, Narodne novine, br. 155/02, 47/10, 80/10.

Ustavni zakon o Ustavnom sudu Republike Hrvatske, Narodne novine, br. 99/99, 29/02, 49/2002 - prečišćen tekst.

Zakon o osobnoj iskaznici, Narodne novine, br. 11/2002.

Закон о ратификацији споразума између Србије и Црне Горе и Републике Хрватске о заштити права српске и црногорске мањине у Републици Хрватској и хрватске мањине у Србији и Црној Гори, Службени лист СЦГ - Међународни уговори, број 3/2005.

Zakon o romski skupnosti v Republiki Sloveniji, Uradni list Republike Slovenije, št. $33 / 07$.

Zakon o samoupravnih narodnih skupnostih, Uradni list Republike Slovenije, št. 65/94 in 71/17 - ZFO-1C.

Zakon o uporabi jezika i pisma nacionalnih manjina u Republici Hrvatskoj, Narodne Novine, br. 51/00, 56/00

Закон о службеној употреби језика и писама, Службени гласник Републике Србије, бр. 45/91, 53/93, 67/93, 48/94, 101/2005 - др. закон, 30/2010, 47/2018 и 48/2018 - испр. 


\title{
Остали извори
}

Решени предмети од стране Уставног суда Републике Хрватске у периоду од 1990. до 30. 06. 2020. https://www.usud.hr/sites/default/files/dokumenti/Pregled_rijesenih_ predmeta_u_razdoblju_od_1990._do_30._lipnja_2020.pdf

Примљени предмети од стране Уставног суда Републике Хрватске у периоду од 1990. до 30. 06. 2020. https:/www.usud.hr/sites/default/files/dokumenti/Pregled_ primljenih_predmeta_u_razdoblju_od_1990._do_30._lipnja_2020.pdf

Уставносудска пракса у Хрватској. https://sljeme.usud.hr/usud/praksaw.nsf

Katinka Beretka

\section{PRACTICE OF THE CONSTITUTIONAL COURT OF THE REPUBLIC OF CROATIA IN FIELD OF NATIONAL MINORITY RIGHTS, WITH SPECIAL REGARD TO LINGUISTIC RIGHTS OF THE SERBIAN COMMUNITY IN CROATIA}

\begin{abstract}
In the period from 2000 to the present day, the Constitutional Court of the Republic of Croatia has often faced the challenge of deciding on politically sensitive topics, especially when it comes to the need to protect the rights of both traditional and so-called "new" minority communities (which emerged from the constituent nations of the former Yugoslavia by the formation of new independent nation-states). The cases that occur in court practice are diverse, but mainly refer to cultural autonomy, representation of persons belonging to national minorities in local or regional representative bodies and equal representation in the public sector, as well as (official) use of language and script. The submitters of constitutional complaints, and the initiators of the procedures for assessing the constitutionality and legality of general legal acts, were guided by various motives; and the question is whether these motives influenced the work of the constitutional court, or in other words, whether the court remained faithful to its original role of protecting the basic, timeless values of the constitutional order of Croatia or was guided by current party policy programs.

In addition to the general presentation of the legal regulation of minority rights, and the jurisdiction of the Constitutional Court in Croatia, the paper analyzes cases related to the language rights of "new" minority communities, focusing on the arguments of both "parties" in the procedure and the constitutional court, as well. The goal of this paper is to present the practice of the Constitutional Court of Croatia in the field of language rights of national minorities through specific constitutional court cases, with special reference to the consistency of the court's argumentation.
\end{abstract}

Keywords: Croatia, constitutional court, national minorities, new minorities, language rights, official use of language 